\title{
A constituição das memórias sobre a repressão da ditadura: o projeto Brasil Nunca Mais e a abertura da vala de Perus
}

Janaína de Almeida Teles*

Resumo: A transição brasileira para a democracia ocorreu sem rupturas evidentes. Sob a forte presença do legado ditatorial, a reconstituição factual e a reflexão crítica acerca do período autoritário permeiam-se por zonas de silêncio e interdições. A formação da memória sobre a repressão da ditadura teve dois eventos fundamentais, a publicação do projeto Brasil Nunca Mais e a abertura da vala de Perus. O principal objetivo deste estudo é oferecer um panorama reflexivo sobre a interdição do passado recente, estabelecendo uma narrativa sobre a formação da memória social a partir destes momentos 'fundacionais', que empurraram os limites de transição pactuada a que o país assistiu. O panorama oferecido beneficia-se de entrevistas com pessoas diretamente envolvidas nesses eventos, documentos pouco explorados (i.e., anais da CPI da vala de Perus) e uma ampla revisão da bibliografia existente sobre o assunto.

Palavras-chave: Transição Política. Tortura. Mortos e desaparecidos políticos. Ditadura e Memória.

\footnotetext{
* Pesquisadora do Programa de Pós-Doutorado em História Social da Universidade de São Paulo. Mestre e Doutora em História Social pela mesma instituição. Coorganizadora de Intolerância e Resistência: Testemunhos da repressão política no Brasil (19641985). São Paulo, FFLCH/USP, 2010; e de Desarquivando a Ditadura. Memória e Justiça no Brasil. São Paulo: Hucitec, 2009, v. 1 e 2, entre outros.
} 


\section{Introdução}

No Brasil, a transição para a democracia ocorreu sem rupturas evidentes. Sob a forte presença do legado ditatorial, a reconstituição factual e a reflexão crítica acerca do período autoritário permeiamse por zonas de silêncio e interdições. Decorridos pouco mais de 27 anos desde o fim do regime de exceção, muitos acontecimentos permanecem desconhecidos ao mesmo tempo em que se observa a existência de importantes lacunas nas articulações entre o passado e o presente, no que tange ao legado da ditadura e à memória daqueles que a ela se opuseram ativamente.

Visando a contribuir para o entendimento deste processo histórico, este texto procura caracterizar a formação das memórias sobre a repressão da ditadura, marcadas por dois eventos fundamentais, a publicação do projeto Brasil Nunca Mais (1985) e a abertura da vala de Perus (1990). O principal objetivo deste estudo é oferecer um panorama reflexivo sobre a interdição do passado recente, estabelecendo uma narrativa sobre a formação da memória social a partir desses momentos 'fundacionais', que empurraram os limites de transição pactuada a que o país assistiu.

Para alcançar tais objetivos, este estudo pauta-se pelo registro das memórias dos presos políticos, advogados e ativistas de direitos humanos. O panorama oferecido beneficia-se de um conjunto de entrevistas constituído ao longo da minha pesquisa de doutorado (TELES, 2011) e de outras realizadas com pessoas diretamente envolvidas nestes eventos, além de documentos pouco explorados (o relatório e os anais da CPI da vala de Perus) e de uma ampla revisão da bibliografia existente sobre o assunto. Tanto o registro memorialístico quanto a análise da documentação permitiram-nos traçar um quadro a respeito da organização do projeto Brasil Nunca Mais e da investigação que se seguiu à abertura da vala de Perus, assim como aprofundar nosso conhecimento sobre as disputas políticas estabelecidas nesse período.

Os testemunhos compilados e os documentos consultados revelaram a efetiva importância desses eventos históricos para a sistematização e divulgação das denúncias dos crimes ocorridos durante a ditadura, os quais contribuíram decisivamente para a 
democratização do país e para a formação das memórias sobre a repressão estatal do período.

Sob esta perspectiva, o estudo caracteriza-se pela abordagem escolhida para a produção do panorama desse período em que estavam em conflito novas e velhas leituras do passado. Neste momento de mudanças, alguns atores e setores sociais buscaram exibir marcas simbólicas e efetivas de rompimento com o passado recente, sistematizando e divulgando as denúncias dos crimes da ditadura, tendo em vista propostas e mecanismos de recuperação da verdade jurídica e histórica capazes de transmitir as memórias e o legado da violência da ditadura. Destacam-se aqui as relações nas quais esses sujeitos históricos estavam inseridos, abrindo uma janela de oportunidades para uma visão singular dos acontecimentos e dados compilados.

\section{A conflituosa história das memórias}

$\mathrm{Na}$ atualidade, a relação entre história e memória (RICOEUR, 2007) e a reflexão sobre a temporalidade, o passado e os processos de mudanças sociais tornaram-se uma preocupação central e estão presentes em diversos campos do conhecimento (TRAVERSO, 2007). Em todos estes domínios, tornou-se lugar comum considerar que, ao contrário da facticidade do passado que não pode ser alterada, o seu sentido forçosamente se transforma ao sabor das intenções, disputas políticas e expectativas. Esta dinâmica aproxima o passado do futuro quanto à abertura e da indeterminação, assim como no que tange à porosidade à ação dos sujeitos históricos.

Esta peculiaridade abre a possibilidade de se utilizar o passado para se estabelecer e transmitir determinadas narrativas. "Ainda que os feitos não sejam apagáveis e não se possa desfazer o que está feito, nem fazer com que o que sucedeu não suceda mais, o sentido do que passou, pelo contrário, não está fixado de uma vez por todas" (RICOEUR, 1999, p. 49 apud JELIN, 2002, p. 39).

O debate em torno da atribuição de sentido a esta estrutura dinâmica que é o passado, vincula-se à análise dos processos e atores sociais envolvidos na construção e formalização das memórias, 
especialmente sobre feitos notáveis e eventos transversais à passagem do tempo. Os atores sociais diversos lutam para afirmar a legitimidade de sua posição, em face de seus vínculos com o passado, estabelecendo continuidades ou rupturas com o mesmo.

As construções divergentes e disputas trazem à tona o papel central dos agentes estatais no estabelecimento e na elaboração das histórias e memórias oficiais, as quais podem ou não se tornar hegemônicas, junto aos intentos que visam a definir e reforçar sentimentos de pertencimento alinhavados para a manutenção da coesão social e a defesa das fronteiras simbólicas.

Como toda narrativa, as versões oficiais são seletivas, embora nem todas devam ser consideradas tão enviesadas ideologicamente quanto à maioria das versões oficiais da história (WINTER, 2006). Ressaltar certos traços com sinais de heroísmo implica silenciar outros, especialmente os erros e as derrotas. Frente à narrativa oficial transmitida pela educação formal, constroem-se também relatos e sentidos diferentes do passado mantidos pela memória e a transmissão oral, práticas de resistência frente ao poder, muitas vezes constituídos nos âmbitos da intimidade ou da clandestinidade (JELIN, 2002, p. 39-42).

Transições políticas determinam esferas públicas singulares, em que narrativas antes silenciadas podem ganhar a luz, gerando novos sentidos e relatos. Tais momentos de mudança institucional são importantes para a memória por vários motivos, entre os quais se destacam as alterações propiciadas na relação entre Estado e sociedade, em face das tensões que permeiam a construção do legado do regime anterior e seu sentido.

Por vezes, as memórias de quem foi oprimido e marginalizado, afetado pela prisão, tortura, assassinatos e desaparecimentos forçados ou exílio, surgem através do testemunho a exigir justiça. Nesses momentos, memória, verdade e justiça permeiam-se.

Historicamente, sabe-se que a posição do Estado raramente se mostra unitária em tal contexto, estando antes articulada em diferentes camadas e direções frente à multiplicidade dos sentidos em disputa. Dir-se-ia que esses momentos de mudança política e social representam "um novo intento fundacional" (JELIN, 2002, p. 43-44), em que estão em conflito novas e velhas leituras do passado. 
No Brasil pós-ditadura, a disputa pela memória foi marcada pela publicação do relatório do projeto Brasil Nunca Mais (BNM), em 1985. Dir-se-ia que se trata de um ato fundacional na construção da memória social sobre os crimes da ditadura, o qual favoreceu a constituição de uma consciência coletiva acerca da política repressiva do período e do status dos sobreviventes. O livro baseia-se em uma vasta documentação, encontrada nos arquivos da justiça militar, que a partir de então pôde ser instrumentalizada para a formação escolar e acadêmica, assim como para a sistematização de denúncias, as quais vêm se desdobrando lentamente, em diversos sentidos (CAPELATO, 2007, p. 14-17).

Nos dois anos subsequentes à sua publicação, o BNM foi a obra literária mais vendida do Brasil (LIMA, 2003), superando a marca de 300 mil exemplares. Suas 38 edições sucederam-se até 2009, ano no qual se completaram os 30 anos da Lei da Anistia.

O segundo ato memorialístico fundamental sobre o período foi a abertura da vala clandestina de Perus, em setembro de 1990. Este evento pautou-se pela busca dos restos mortais de militantes assassinados pela repressão estatal na ditadura e obteve grande repercussão junto à opinião pública, com efetivas consequências investigatórias.

Em seguida à descoberta da vala clandestina encontrada em Perus, iniciaram-se as escavações e pesquisas de antropologia forense. Estas foram acompanhadas pela instauração de uma Comissão Parlamentar de Inquérito (CPI) na Câmara Municipal de São Paulo, com o objetivo de apurar os crimes cometidos. A abertura dessa vala influenciou o desvelo de outras valas clandestinas com restos mortais de militantes assassinados, no Rio de Janeiro e em Pernambuco, em 1993 (CAPELATO, 2009, p. 28-29). A repercussão nacional desses fatos favoreceu a pesquisa nos arquivos do Instituto Médico Legal (IML) de São Paulo, a partir da iniciativa de familiares e da CPI. O mesmo veio a acontecer no IML do Rio de Janeiro. A pedido dos familiares, o presidente Fernando Collor promoveu a abertura dos arquivos das polícias políticas estaduais, os DEOPS, a partir de 1991. Este processo culminou na criação da Comissão de Direitos Humanos do Congresso Nacional e a promulgação da Lei dos Mortos e Desaparecidos Políticos (lei 9.140), em 1995. 
As iniciativas relativas às escavações e investigações, porém, foram realizadas com pouco apoio oficial. O balanço desta experiência demonstra que o período inicial de democratização foi sistematicamente marcado por mecanismos de denegação e bloqueio de processos de responsabilização. Esta conjuntura impediu a profusão de procedimentos judiciais e extrajudiciais de recuperação factual, a qual acabou limitada, em grande medida, à sistematização e divulgação de relatórios e informes. Essas ausências têm dificultado a realização de um amplo e efetivo debate na sociedade brasileira sobre o legado de violência da ditadura, contexto no qual o presente artigo se insere, juntamente com outros.

\section{O marco inaugural da memória sobre a ditadura: o projeto Brasil Nunca Mais}

O projeto de pesquisa Brasil Nunca Mais inaugurou as operações de memória sobre a ditadura, no período de democratização. O projeto foi organizado com o apoio decisivo de d. Paulo Evaristo Arns, da Arquidiocese Metropolitana de São Paulo, e coordenado pelo reverendo presbiteriano Jaime Wright, entre agosto de 1979 e março de $1985^{1}$. Para sua realização, foram consumidos mais de 350 mil dólares, em valores da época, fornecidos pelo Conselho Mundial de Igrejas (CMI). Nele trabalharam advogados, ex-presos políticos, militantes de defesa dos direitos humanos, historiadores, cientistas políticos, psicólogos, técnicos em informática e jornalistas. Com a extinção do AI-5 e a reformulação da Lei de Segurança Nacional (LSN), em dezembro de $1978^{2}$, alguns advogados de presos políticos puderam solicitar e copiar os processos de seus clientes no Supremo Tribunal Militar (STM). Membros do projeto lograram copiar secretamente 707 processos completos e dezenas de outros incompletos, do período transcorrido entre 1964 e 1979, reunindo cerca de 1,2 milhão de páginas, com testemunhos e documentos produzidos pelo aparato repressivo ou por ele apropriado dos grupos dissidentes.

Este material foi submetido a uma metodologia de análise, que resultou na elaboração de 12 volumes com as conclusões da pesquisa, 
somando 6.891 páginas $^{3}$. Em seguida, os jornalistas Ricardo Kotscho e Frei Betto escreveram a síntese do projeto, publicada no livro BrasilNunca Mais, constituindo-se, desde o início, num marco, dando grande visibilidade às denúncias dos crimes cometidos pela ditadura.

Parte disso foi possível porque parcela dos perseguidos políticos submetidos aos tribunais de exceção, controlados pela justiça militar desde 1965, fizeram declarações em juízo que continham denúncias das torturas sofridas, nas quais mencionavam os nomes dos torturadores e os métodos de sevícia empregados. Há no "Projeto A" 2.700 páginas datilografadas de depoimentos relatando torturas (ARQUIDIOCESE, 1989, p. 25). Mesmo sob ameaça de voltarem a ser torturados, 1.843 pessoas (25\% dos réus) revelaram as torturas e os assassinatos a que foram submetidos ou testemunharam. Relatos referem-se às ameaças e à existência de uma sala utilizada para torturar no porão da II Auditoria Militar, de São Paulo (MACHADO, 2009). Desse modo, a ditadura acabou por documentar parte das violações aos direitos humanos que praticava e manteve esses documentos em arquivo no STM.

A obra revelou, pela primeira vez, com provas irrefutáveis, a atuação do terrorismo de Estado instaurado em 1964 e suas estratégias de repressão. O livro analisa as origens do aparelho repressivo e sua estruturação. Descreve as ilegalidades cometidas nos processos da justiça militar, desde o momento da constituição dos Inquéritos Policiais Militares (IPM) até os julgamentos dos réus enquadrados na LSN e o comportamento conivente das autoridades judiciais, passando pelo estudo da legislação de exceção, constantemente desrespeitada. Relata de modo sucinto a participação de médicos tanto no auxílio à tortura quanto na falsificação de laudos necroscópicos. Nomeia e descreve diversos centros de tortura. Divulga partes dos depoimentos feitos em juízo, à época, dando voz às vítimas e adotando seu ponto de vista.

A história da concepção, organização, execução e o processo para editar a publicação do BNM ainda é parcialmente desconhecida. Passados muitos anos após o fim da ditadura, os membros do projeto têm preferido manter discrição a respeito dessa história. Algumas iniciativas procuram reverter esta lacuna ${ }^{4}$. Os riscos e obstáculos enfrentados pelo projeto foram muitos, tendo em vista que ele foi 
realizado ainda durante a ditadura e iniciado no momento em que estavam em disputa vários projetos de anistia, em que o tema da tortura, dos assassinatos e desaparecimentos forçados estava em evidência.

Em maio de 1979, após acirrada disputa, familiares de mortos e desaparecidos políticos e deputados "autênticos" do MDB recuperaram a proposta de formação de uma CPI sobre a Tortura (ou sobre os Direitos Humanos), que gerou a chamada "Crise dos desaparecidos", no primeiro semestre de 1975. Apesar de alguns deputados mais à esquerda do partido declararem-se contrários à formação da CPI, o MDB aprovou a proposta, mas manobras regimentais impediram que ela fosse apresentada ao Congresso Nacional. Em agosto daquele ano, foi aprovada a lei de anistia com uma redação ambígua, o que favoreceu a interpretação de que ela era recíproca, contemplando torturados e torturadores (TELES, 2005).

O período após a aprovação da anistia viu crescer o acirramento dos atentados terroristas organizados clandestinamente por agentes dos órgãos de segurança interna. Ocorreram os atentados a bomba contra bancas de jornal que vendiam periódicos da imprensa alternativa em várias cidades do país, culminando nos atentados contra a Ordem dos Advogados do Brasil (OAB), a Associação Brasileira de Imprensa (ABI) e a Câmara Municipal do Rio de Janeiro, que levaram à morte da secretária da OAB, Lyda Monteiro, em 27 de agosto de 1980 (ALMEIDA, 2009, p. 712-713).

Em fevereiro de 1981, a Casa da Morte, localizada em Petrópolis (RJ), utilizada pelo Centro de Informação do Exército (CIE) para torturar, matar e desaparecer dissidentes, foi descoberta e denunciada, provocando uma dura reação por parte dos militares contrários a qualquer tipo de investigação do passado recente (TELES, 2005). Em abril daquele ano, houve ainda a tentativa de executar o que teria sido o maior atentado terrorista, durante um show realizado no Riocentro, com a presença de milhares de pessoas, frustrado pela inépcia dos militares do CIE encarregados de colocar a bomba no local. O caso do Riocentro, que possuía muitas evidências a respeito da sua autoria, teve a investigação protelada e arquivada. Esses fatos justificavam as preocupações com os riscos decorrentes da realização do BNM. Os riscos eram bastante concretos e presentes, o que explica o sigilo criado em torno dele. 
O projeto teve entre seus principais colaboradores os advogados Eny Raimundo Moreira, Luiz Eduardo Greenhalgh, Luís Carlos Sigmaringa Seixas e Mário Simas, os jornalistas Paulo Vannuchi, Ricardo Kotscho e Frei Betto, a socióloga Vânya Santana ${ }^{5}$ a historiadora Ana Maria de Almeida Camargo (CAMARGO, 2011), entre outros. De acordo com o relato de Eny Raimundo, advogada de presos políticos, a ideia do projeto surgiu de uma preocupação do jurista Sobral Pinto, em cujo escritório trabalhava, que repetidas vezes contava a história da destruição dos documentos do Tribunal de Segurança Nacional do período do Estado Novo, provavelmente queimados ou eliminados. Durante o ano de 1978, com o impulso da luta pela anistia, Eny, então presidente do Comitê Brasileiro de Anistia do Rio de Janeiro, começou a procurar parceiros que a ajudassem, até chegar ao CMI, sediado na Suíça. Os objetivos apresentados ao secretário de direitos humanos na América Latina da entidade, pastor Charles Harper, eram preservar a documentação sobre a repressão estatal e produzir uma análise histórica e jurídica que contribuísse para uma melhor compreensão da ditadura brasileira, além de realizar uma história das práticas de tortura no país. Ele deu total apoio à proposta e solicitou-lhe que ela procurasse D. Paulo e o reverendo Jaime Wright (MOREIRA, idem).

Eny conseguiu o aval dos dois e o projeto começaria com uma equipe de advogados, predominantemente do Rio de Janeiro, que contaria com a ajuda de Sobral Pinto e seria composta por Heleno Fragoso, Bento Rubião, Rosa Maria Cardoso, um historiador e um cientista político, entre outros. D. Paulo, contudo, pediu-lhe que o projeto fosse sediado em São Paulo, único lugar onde poderia garantir segurança à equipe e ao material copiado. Assim, a equipe foi modificada, pois a maioria não tinha disponibilidade para se deslocar para São Paulo (MOREIRA, idem).

De acordo com Sigmaringa Seixas, o advogado responsável pela retirada e reprodução dos processos do STM, em Brasília, em dois anos, foi possível realizar as cópias de 1.000 processos (707 completos), usando como pretexto a Lei de Anistia. Os advogados necessitavam consultar os processos para saber se seus clientes poderiam ser anistiados ou não. O projeto envolvia um grande volume de material, obtido por meio de trabalho intenso de cópia de 
centenas de milhares de páginas, mas, durante os cinco anos de sua realização, não despertou maiores suspeitas. Em cada fase do projeto, eram contratados especialistas e assim foram envolvidas cerca de 30 pessoas no trabalho. Todas as informações foram tratadas com cuidado e rigor, pois o projeto deveria ser uma denúncia, mas também um legado para as gerações futuras.

A equipe mudou-se de lugar mais de uma vez. Permaneceram cerca de um ano numa sala do prédio do Sedes Sapientiae, com o apoio de Madre Cristina. Depois, por motivos de segurança, foram transferidos para as dependências de um seminário localizado no bairro do Ipiranga e, em seguida, para uma igreja situada na alameda Franca, no Jardim Paulista 6 .

Carlos Lichtsztejn, um guerrilheiro da Ação Libertadora Nacional (ALN) preso em 1969, trabalhou no projeto durante quatro anos. Ele nos contou sobre a atmosfera de trabalho e sobre a organização e execução do BNM:

Era totalmente secreto, nós estávamos na ditadura, em 1980 as pessoas tinham muito medo, para arrumar pessoas para trabalhar nisso era muito difícil. Aí conseguiu-se meia dúzia de pessoas que achavam importante esquadrinhar os crimes da ditadura com os seus próprios documentos. Isso era o que tinha de original nesse projeto [...].

No início, a gente fazia de tudo. Pegávamos processo por processo, pois havia um roteiro com um questionário que a gente ia preenchendo. Assim, classificávamos todas as irregularidades, todos os abusos, torturas, os prazos...

[...] A informática foi uma mão na roda, mas a gente trabalhava com computadores quase que movidos a lenha. A partir de certo momento, fiquei responsável por essa parte. [...] Foram horas e horas de digitação, comparado com hoje, eram condições precaríssimas, o computador era o CP 500. [...] Chegou uma época, que havia falta de condições para acabar aquilo em um prazo viável. Então, começamos a reestruturar o projeto e decidiu-se por contratar um monte de gente para trabalhar na pesquisa dos dados, informática, história, jornalistas, entre outros (LICHTSZTEJN, 2010). 
De acordo com Paulo Vannuchi, ex-preso político e exSecretário Nacional dos Direitos Humanos, o que havia sido pensado como um estudo sob o enfoque jurídico foi se transformando num extenso levantamento e em uma análise de tudo aquilo que aflorava dos mecanismos da justiça militar em relação aos direitos humanos (VANNUCHI, Idem). Eny Moreira menciona ter havido divergências sobre o enfoque da análise e a maneira de apresentar o projeto, sem esclarecer quais seriam as diferenças, declarando apenas que foi voto vencido.

Luis Eduardo Greenhalgh relata que houve muita discussão entre os participantes do projeto sobre como deveria ser o livro resultante e seu formato de divulgação:

Nós discutimos muito e havia duas posições: tinha uma que
dizia que não dava para fazer um livro extensivo sobre o que
nós achamos nos processos, tínhamos que fazer um pequeno
resumo, para que tivesse impacto na sociedade brasileira.
E tinha outras pessoas que falavam: não dá pra fazer uma
pesquisa de seis anos, clandestina, cheia de riscos, e depois
fazer um resumo dela, é muito pobre isso, temos que publicar
extensivamente os locais e os centros de tortura, as pessoas
que foram torturadas, a lista dos torturadores, os laudos, pistas
sobre desaparecidos, os métodos e os tipos de tortura, os
locais das torturas no Brasil durante o regime militar. [...] D.
Paulo era a favor de fazer o livro extensivo, divulgando ipsis
literis o que nós tiramos dos processos, até porque assim não
tinha como a repressão contestar. [...] Jaime Wright achava
que, além disso, devíamos fazer um resumo. Aí consultamos
outras pessoas, entre as quais o Ricardo Kotscho e o Frei
Betto, e a maioria defendia que dava pra fazer as duas coisas?.

De fato, as duas propostas de divulgação foram encaminhadas parcialmente, a versão que se tornou conhecida da maioria das pessoas foi o livro. Não sabemos, porém, como lidaram com as divergências referentes ao conteúdo. Inicialmente, a equipe resolveu adiar a publicação do livro até depois da posse do presidente civil eleito indiretamente pelo Congresso Nacional, Tancredo Neves, 
marcada para 15 de março de 1985. Eles não queriam arriscar-se a provocar o cancelamento da posse e possíveis represálias provocadas por militares (WESCHLER, 1990, p. 75).

Segundo Vannuchi, em maio de 1985, José Sarney, já então presidente do país, deu sinais de que era possível lançar o livro. Neste momento, iniciaram-se as discussões sobre a formação do Congresso Constituinte e Sarney recebeu os dirigentes do PCB e do PCdoB para discutir a proposta de emenda constitucional que permitiria a legalização dos dois partidos. Ele ainda encaminhou ao Congresso uma proposta de alterações de alguns elementos restritivos da Lei de Anistia (VANNUCHI, idem), direcionando-a para o aspecto trabalhista, com desdobramentos relativos ao pagamento de reparações a alguns setores de sobreviventes.

Os nomes dos torturadores não foram publicados no livro, pois a equipe decidiu suspender a publicação da lista dos 444 torturadores até que a situação política pudesse afirmar-se. O BNM foi chamado pelos seus realizadores até as vésperas do lançamento de Testemunhos para a paz. Com a doença do presidente eleito Tancredo Neves, o lançamento do livro foi adiado para 15 de julho, quando efetivamente chegou às livrarias. Os organizadores do projeto esperaram até o dia 21 de novembro daquele ano para liberar a lista dos torturadores aos jornalistas, ou seja, poucos dias depois das primeiras eleições municipais realizadas sob um regime civil (WESCHLER, 1990, p. 75, p. 82). Essa lista era uma continuidade do levantamento elaborado pelos presos políticos de São Paulo, contendo 233 nomes de torturadores, encaminhado ao presidente da OAB em 26 de outubro de 1975. Apenas em 1978 esta lista foi publicada pelo jornal Em Tempo, o qual publicou outra lista contendo 444 nomes de torturadores no ano seguinte. Estas listas foram organizadas pelos presos políticos ao longo da década de 1970 (TELES, 2011).

O BNM refletiu as ambiguidades e os limites da transição política brasileira que ainda marcam a construção das memórias sobre a ditadura. Ao analisarmos os prefácios de d. Paulo Arns e de Philip Potter, da CMI, de maio e junho de 1985, e a apresentação do livro, é possível destacar alguns aspectos que chamam atenção a respeito da atmosfera, das preocupações e dos posicionamentos dominantes da época. 
Preocupado com o clima de insegurança institucional que o início do primeiro governo civil inspirava, o prefácio de d. Paulo faz referência ao legado de Cristo, ele mesmo "perseguido, torturado e morto" e menciona sua missão de trabalhar pela "justiça, verdade, liberdade e amor". Primeiro, relata o sofrimento das mães e dos parentes de desaparecidos políticos, os quais se transformam " [...] numa sombra que ao escurecer-se vai encobrindo a última luminosidade da existência terrena". E, por fim, descreve casos de tortura, cujos relatos ouviu diretamente das vítimas.

A apresentação do livro ressalta a função pedagógica da história e sua importância, auxiliando para que "nunca mais" se repitam os erros e crimes do passado recente. O livro é definido como uma "[...] reportagem sobre uma investigação no campo dos Direitos Humanos. É uma radiografia inédita da repressão política que se abateu sobre milhares de brasileiros considerados pelos militares como adversários do regime instaurado em abril de 1964. É também a anatomia da resistência" (ARQUIDIOCESE, 1989, p. 21). A militância política dos sobreviventes e das vítimas fatais não foi subtraída, mas somente em 1987 saiu publicado o livro Perfil dos Atingidos, o tomo III do Projeto $A$, onde consta um extenso levantamento sobre os grupos de esquerda (ARQUIDIOCESE, 1987).

A utilização exclusiva de fontes oficiais é a característica principal assinalada pelos organizadores do projeto e o fator decisivo que garantiu à obra confiabilidade e legitimidade:

No mundo todo, a questão da repressão política é quase sempre levantada a partir de denúncias de atingidos, ou de relatos elaborados por entidades que se dedicam à defesa dos Direitos Humanos. Emotivos ou equilibrados, são testemunhos que ajudam a revelar uma história oculta. Mas tropeçam, às vezes, na desconfiança daqueles que alegam serem depoimentos tendenciosos, por partirem de vítimas que, na sua maioria, teriam motivações políticas.

A pesquisa 'Brasil Nunca Mais' (BNM) conseguiu superar esse dilema, estudando a repressão exercida pelo Regime Militar a partir de documentos produzidos pelas próprias autoridades encarregadas dessa tão controvertida tarefa. [...] 
Pode-se argumentar que, dispensando a tomada de depoimentos das próprias vítimas, e trabalhando com documentos produzidos pelas autoridades do regime, o Projeto estaria condenado a apurar apenas pequena parte das violências cometidas contra os Direitos Humanos no período. A fonte documental podia ser comparada a um material de onde os agentes da repressão removeram as "impressões digitais" dos crimes cometidos no ato de investigar.

Mas havia uma contrapartida compensadora: o que se produzisse como constatação de irregularidades, de atos ilegais, de medidas injustas, de denúncias sobre torturas e mortes, teria a dimensão de prova indiscutível. Definitiva (ARQUIDIOCESE, 1989, p. 22, p. 24).

O risco foi calculado, segundo Vannuchi esta foi uma opção que se mostrou "historicamente acertada" (VANNUCHI, Idem). $\mathrm{O}$ BNM de fato influenciou e foi fundamental para todas as iniciativas de resgate da história da ditadura, ajudando pesquisadores com informações e sustentando investigações. O caráter oficial da documentação e, principalmente, sua origem nos tribunais de exceção forneceram, no entanto, informações com determinadas características, que em muitos casos não levaram ao esclarecimento dos assassinatos sob tortura e dos desaparecimentos forçados, nem do funcionamento dos centros de tortura e extermínio.

Não obstante, há muita informação neste acervo, sob todos os aspectos e, principalmente, tendo em vista que são processos da justiça militar. $\mathrm{O}$ volume 4, do tomo $\mathrm{V}$, é dedicado aos mortos e contém os testemunhos, citados nos autos dos processos judiciais, de pessoas que presenciaram nos cárceres a morte de outros presos sob tortura, desmentindo as versões de que teriam ocorrido em tiroteios com agentes do governo ou em atropelamentos ${ }^{8}$. Baseado nos processos judiciais, obrigatoriamente, o BNM possui mais informações sobre os sobreviventes, conforme se pode perceber pelo espaço menor dedicado à temática dos mortos e desaparecidos, tanto no livro como no Projeto $A$.

Um espírito de conciliação está presente no texto de apresentação, o qual se escora em uma interpretação do conceito de justiça 
no Brasil que, segundo os autores, faz-se alheio ao de vingança. Para desenvolverem esta exposição de ideias, utilizam termos extraídos da retórica militar, como "revanche" e "vingança" - não havendo no texto menções diretas a conceitos classicamente associados à reflexão acerca do estado de direito, tais como "lei" e "direito". A perspectiva apontada como sendo principal é a da recuperação da "verdade" histórica:

Não é a intenção do Projeto organizar um sistema de provas para a apresentação em qualquer Nuremberg brasileiro. Não o anima qualquer sentido de revanche. $\mathrm{Na}$ busca de justiça, o povo brasileiro nunca foi movido por sentimentos de vingança. [...] É a observância do preceito evangélico que nos aconselha o conhecimento da verdade como pressuposto para a libertação (ARQUIDIOCESE, 1989, p. 26).

Philip Potter, do CMI, identificou a Igreja Católica como uma instituição defensora dos direitos humanos, sem fazer referências ou críticas ao seu posicionamento favorável a golpes e ditaduras em nome do combate à ameaça comunista, no Brasil e no continente (BAUER, 2008, p. 12): “[...] os Católicos têm estado nas fronteiras da luta pelos direitos humanos na América Latina, sendo que muitos padres e religiosos foram torturados até a morte" (ARQUIDIOCESE, 1989, p. 17). Evocou ainda o sofrimento como remissão e o perdão aos torturadores, fortalecendo a "solução conciliadora" e a equiparação da violência dos dois lados - guerrilheiros e repressores -, confirmando a interpretação da Lei de Anistia como tendo sido recíproca:

É com penitências, pois, que encaramos este livro. Ele não pretende ser meramente uma acusação, mas sim um convite para que todos nós reconheçamos nossa verdadeira identidade através das faces desfiguradas dos torturados e dos torturadores. Fazemos isso em nome de Cristo que foi torturado e crucificado para que tivéssemos vida em toda a sua plenitude. $\mathrm{Na}$ cruz, Jesus intercedeu pelos seus torturadores: 'Pai, perdoa-lhes, pois não sabem o que fazem' (ARQUIDIOCESE, 1989, p. 18-19). 
Os reflexos institucionais da publicação do livro sentiram-se lentamente. $\mathrm{O}$ pedido de d. Paulo, feito no prefácio, apelando ao governo brasileiro para que assinasse e ratificasse a "Convenção contra a Tortura e outros Tratamentos ou Penas Cruéis, Desumanos ou Degradantes", aprovada pela Assembleia Geral da ONU, em 1984, obteve a assinatura do então presidente Sarney, dois meses após seu lançamento, mas a Convenção só foi ratificada em 15 de fevereiro de 1991. A lei tipificando o crime de tortura somente foi votada no Congresso Nacional e promulgada em 1997.

No âmbito da sociedade civil, a publicação também gerou desdobramentos significativos, tais como o surgimento dos grupos constituintes do movimento Tortura Nunca Mais, com destaque para o primeiro grupo, surgido em 1985, no Rio de Janeiro, e composto por ex-presos políticos e familiares de mortos e desaparecidos políticos?.

Esses desdobramentos, no entanto, não levaram à realização de "julgamentos pela verdade" ou a ações civis ou penais contra os torturadores e mandantes como na Argentina. Este tema foi discutido pelos organizadores do BNM; refletindo sobre isto, Carlos Lichtsztejn, assim como outros entrevistados nesta pesquisa, destaca a ausência de hipóteses bem definidas para o entendimento desta falta de processos judiciais contra os torturadores:

A gente fez essa discussão [...]. O Jaime Wright participava [...], o d. Paulo não. [...] Era muito claro e estava correto pensar que aquilo era uma documentação valiosa para incriminar a ditadura, que seria fundamental para mostrar, condenar, criminalizar todos os torturadores e os responsáveis por isso. Não só aqueles que participaram diretamente da tortura, mas também os mandantes [...], pois aquilo não era uma excentricidade, mas a base do sistema.

[...] Não sei por que esse trabalho nunca foi usado em ações judiciais... Para mim que participei quatro anos desse projeto, realmente, acho que seu resultado efetivo é que, por um lado, do ponto de vista histórico foi muito importante, isso não tem discussão. Porém, eu achava que isso teria uma repercussão na sociedade no sentido de identificar e processar as pessoas que cometeram essas barbaridades. Aquilo era um instrumento, 
eu achava isso fundamental, porque temos o nome da pessoa, onde ela trabalhava e as testemunhas... mas, aí....

[...] Em 1984, me desliguei do projeto. Aconteceram as publicações e isso ficou com a Cúria, o Jaime Wright, eles são os pais do projeto. Enfim, a publicação teve a repercussão que deveria ter, naquele momento, e a consequência esperada por todos que trabalharam nele (LICHTSZTEJN, 2010).

A publicação do BNM permite paralelos e contrastes com a publicação do informe argentino Nunca Más. Este último foi produzido pela Conadep e quase inteiramente sustentado por testemunhos de sobreviventes e familiares, coletados ao longo de nove meses de intensas busca de informações sobre os desaparecidos. O nome da edição do BNM foi inspirado pelo relatório argentino (de novembro de 1984) e publicada alguns meses depois, em julho de 1985.

Apesar das resistências iniciais dos movimentos de direitos humanos contra a formação da Conadep - em especial das Madres da Plaza de Mayo - as pessoas fizeram filas em frente à sua sede para registrar o seu depoimento a esta que tem sido considerada uma das primeiras experiências de organização de uma Comissão da Verdade.

A reivindicação dos movimentos era pela formação de uma Comissão Parlamentar bicameral, exibindo paralelos com o movimento brasileiro para a instituição de uma CPI similar em 1975 e 1979 (TELES, 2005), para apurar todos os crimes cometidos pela repressão estatal e não deixar espaço para qualquer possibilidade de realizarem-se julgamentos dos grupos guerrilheiros. Queriam uma investigação que abrangesse não apenas os desaparecimentos forçados e que fosse realizada por um órgão com poder e independência suficiente para fazer diligências e convocar militares e policiais para depor. Reivindicavam uma comissão que não fosse apenas uma intermediária entre a sociedade civil e a justiça, ao encaminhar as denúncias para o poder judiciário, mas que pudesse realizar também o julgamento político da ditadura. Esta perspectiva contrastava com a determinação de Alfonsin, que assumiu o governo no final de 1983 e no início de seu mandato determinou o processo das juntas militares e da cúpula da guerrilha (CRENZEL, 2008). 
Estes depoimentos, registrados desde as experiências de um contingente populacional inicialmente descrente, que ao final registrou cinco mil quinhentos e oitenta denúncias, mostraram-se fundamentais para a compreensão do que se passou durante os períodos mais sombrios da ditadura argentina - em relação à qual faz-se paradigmática a transição da crença inicial da população de que os desaparecidos estariam vivos (por exemplo, encarcerados em manicômios e prisões secretas) para a percepção da dura realidade que de fato se abatera sobre as vítimas deste regime sangrento.

Diante da ausência de documentos oficiais, os militares supostamente teriam queimado a maioria dos documentos e registros sobre sua atuação repressiva, os relatos se tornaram cruciais. A Conadep convocou as pessoas a testemunharem por meio de chamadas no rádio e na televisão e estabeleceu um plano para realizar visitas ao interior do país. Organizou também viagens ao exterior para ouvir os testemunhos de sobreviventes exilados que temiam fazer declarações nas embaixadas argentinas. Os depoimentos iniciais foram catalisadores de outros e estas iniciativas acabaram por conseguir recolher milhares de denúncias nunca antes registradas. Para maioria dos sobreviventes, tratava-se da primeira interpelação pública sobre suas experiências e recordações (CRENZEL, 2008, p. 71).

Este processo teve êxito em função do acolhimento da prerrogativa da validade intrínseca dos depoimentos, a qual estava inscrita sob a ética do testemunho e do respeito singular pela experiência. Não obstante, diversos sobreviventes deixaram de testemunhar, devido às ameaças e à atmosfera de medo, naquele momento ainda bastante presente ${ }^{10}$. A esta perspectiva cabe adicionar o papel catalisador das exumações de restos mortais de desaparecidos políticos em cemitérios públicos e outras ações efetivas, as quais tiveram grande impacto na opinião pública argentina, sobretudo em face da ampla divulgação do tema nos meios de comunicação.

A Conadep, que iniciou seus trabalhos sem uma estratégia clara de investigação, decidiu então classificar esse vasto material testemunhal por centros clandestinos de detenção, e decidiu fazer inspeções nestes locais, que foram amplamente divulgadas e seus resultados expostos nos meios de comunicação (CRENZEL, 2008, p. 73-75). 
Os testemunhos deram materialidade aos desaparecimentos forçados, permitiram a articulação das informações sobre as fases pública e clandestina da repressão estatal e incrementaram o número conhecido de responsáveis por esses crimes. Estes milhares de testemunhos expressaram um exercício público de evocação que permitiu ampliar o conhecimento sobre a história da ditadura argentina (Idem, p. 75). Este processo culminou com a apresentação dos resultados dos trabalhos da Conadep em um programa de televisão com uma audiência massiva. Assistido por 1.640.000 pessoas, todas as intervenções feitas no programa apelaram à justiça, em especial, sobreviventes e familiares reivindicaram que as responsabilidades não ficassem restritas à cúpula militar (Idem, p. 88-89).

A condenação moral da ditadura inscrita no informe Nunca Más e a importância da sua enorme repercussão, de certa forma, obscureceram a ideologia conservadora expressa em seu prólogo escrito por Ernesto Sábato, no qual o terrorismo de estado foi igualado ética, política e juridicamente às ações efetuadas pelas organizações revolucionárias. Esta posição, conhecida como a "teoria dos dois demônios", foi refutada somente em 2006, no novo prefácio escrito para a edição relativa aos 30 anos do golpe de estado de 1976.

Esta aproximação com o caso argentino pode ajudar-nos a entender a diferença definida para com a experiência brasileira, a qual manteve-se tanto mais aderida às fontes documentais. É de se ter em vista, contudo, que os depoimentos compilados pelo BNM foram realizados em juízo, nos tribunais militares, produzidos em situações coercitivas cercadas por grande risco, mas fundamentais para o conhecimento dos crimes da repressão estatal.

O BNM caracteriza-se, enfim, como a grande fonte documental oriunda de registros oficiais sobre os crimes da ditadura civilmilitar brasileira, compondo parte significativa do panorama informacional existente, o qual por sua vez se completa pelas denúncias dos exilados e dos familiares de mortos e desaparecidos; por aquelas que saíram clandestinamente dos presídios políticos; e, finalmente, pelas provas factuais da violência estatal, entre as quais os restos mortais dos militantes encontrados na vala clandestina de Perus e na região da Guerrilha do Araguaia exercem papel paradigmático. 


\section{A investigação sobre a vala clandestina de Perus}

Entre 1978 e 1979, familiares de mortos e desaparecidos políticos descobriram que militantes assassinados pela repressão política eram sepultados como indigentes no cemitério D. Bosco, localizado em Perus, periferia de São Paulo. Ao pesquisar nos livros de sepultamento, verificaram a existência de registros referentes a militantes mortos ou desaparecidos identificados com nomes falsos, alguns deles utilizados na militância clandestina. Por meio dos relatos de funcionários e do administrador do cemitério, souberam que em 1975 muitas ossadas haviam sido exumadas e enterradas numa vala clandestina no ano seguinte. Naquela ocasião, nada pôde ser feito devido à repressão ainda vigente no país (TELES, 2005).

Em 1990, o repórter Caco Barcellos tomou conhecimento da vala clandestina de Perus ao investigar laudos necroscópicos do Instituto Médico Legal (IML), quando realizava uma investigação sobre a violência policial de São Paulo. A pedido do jornalista, a vala de Perus foi aberta, gerando grande repercussão na imprensa nacional e internacional (BARCELLOS, 2001, p. 208). Na ocasião, a então prefeita Luiza Erundina criou a Comissão Especial de Investigação das Ossadas de Perus, composta por familiares e militantes para acompanhar os trabalhos de identificação das ossadas encontradas e apurar a existência de outras valas comuns nos demais cemitérios da cidade.

Os familiares e defensores dos direitos humanos reivindicaram a transferência das ossadas para o Departamento de Medicina Legal da Universidade Estadual de Campinas (Unicamp), pois no IML de São Paulo ainda atuavam médicos legistas que assinaram laudos falsos de presos políticos assassinados sob tortura. Nesta época, o Dr. José Antônio de Melo era o diretor do IML, o mesmo que assinou o laudo necroscópico de Manoel Fiel Filho, torturado até a morte no dia 16 de janeiro de 1976, no DOI-CODI/SP. Os familiares, o Núcleo de Estudos da Violência da USP (NEV), a Anistia Internacionale a Human Rights Watch-Americas convidaram o Dr. Clyde Collins Snow e a Equipe Argentina de Antropologia Forense (EAAF) para colaborarem com o Departamento de Medicina Legal da Unicamp na catalogação e identificação das ossadas encontradas na vala de 
Perus. Os antropólogos argentinos, porém, não puderam trabalhar nas pesquisas de identificação, pois a equipe de medicina legal da Unicamp não concordou com sua participação nos trabalhos.

A vala possuía 30 metros de comprimento por $50 \mathrm{~cm}$ de largura e 2,70m de profundidade. Nela foram encontradas 1.049 ossadas de indigentes, de vítima dos esquadrões da morte, de crianças vítimas da meningite (desde um surto "censurado" da doença, que ocorrera nos anos 1970) e de perseguidos políticos, assassinados pela repressão ditatorial. Em dezembro de 1990, essas ossadas devidamente catalogadas e embaladas foram transferidas para o DML/Unicamp.

\section{A CPI da vala de Perus}

As exumações de restos mortais de mortos e desaparecidos políticos do cemitério de Perus desempenharam um papel catalisador junto à opinião pública brasileira, sobretudo devido à ampla divulgação do tema nos meios de comunicação. Neste contexto, entre outubro de 1990 e abril de 1991, funcionou na Câmara Municipal de São Paulo a Comissão Parlamentar de Inquérito (CPI) instaurada para investigar as irregularidades relacionadas à vala de Perus. Durante seis meses, a CPI trabalhou na recuperação dos fatos e obteve informações e provas irrefutáveis sobre a organização de um esquema formado por militares, a polícia política (DEOPS) e médicos legistas do IML/SP, para ocultar as causas das mortes e os cadáveres de perseguidos políticos assassinados. Em 42 sessões ordinárias e uma extraordinária, foram ouvidos os depoimentos de 82 pessoas entre sobreviventes, militares, policiais, médicos legistas, um ex-prefeito e dois ex-governadores, e recuperados centenas de documentos, somando aos autos 10 mil folhas.

A CPI iniciou seus trabalhos sob o impacto da abertura da vala e sem uma estratégia clara de investigação, conforme o testemunho da então vereadora Teresa Lajolo ${ }^{11}$ :

De repente, a gente ficou sabendo da existência da vala de Perus e, logo em seguida, tornei-me a relatora da CPI. Aquilo foi uma surpresa. Tivemos de entender o que era essa 
história. A primeira providência que tomamos foi entrar em contato com os familiares de mortos e desaparecidos políticos e fizemos várias reuniões informais. Eles nos contaram a história da vala e a partir das informações que eles haviam levantado começamos a esboçar o que deveríamos investigar e quem seria convocado para depor. Não havia um plano estabelecido, nem estavam definidos quais critérios iríamos utilizar. Convocávamos as pessoas para depor conforme apareciam as informações (LAJOLO, 2012).

A CPI utilizou o BNM, o Dossiê dos Mortos e Desaparecidos Políticos a partir de 1964 da Comissão de Familiares e o livro Tortura, do jornalista Antonio Carlos Fon, como guias para o trabalho de investigação. Além disso, fez inspeções nos cemitérios da cidade e em possíveis centros de tortura clandestinos; e colheu vasta documentação do Serviço Funerário Municipal (SFM) e da administração pública à medida que os depoimentos foram sendo coletados.

Na primeira fase, foram ouvidos funcionários e ex-funcionários, ex-administradores do cemitério d. Bosco e membros do SFM. Em seguida, a CPI ouviu os depoimentos de funcionários, médicos legistas e administradores do IML. As declarações destes levaram a CPI a chamar para depor os funcionários e delegados do antigo DEOPS (extinto em 1983). Estes testemunhos fizeram diversas referências a integrantes do DOI-CODI/SP, que também foram ouvidos pela CPI. Alguns deles, tais como Carlos Alberto Brilhante Ustra, Benoni de Arruda Albernaz e Dalmo Luiz Cirillo foram convocados, mas não compareceram. Estes depoimentos foram entremeados pela tomada dos testemunhos de ex-presos políticos, familiares de mortos e desaparecidos políticos e de militantes de defesa dos direitos humanos.

De acordo com os dados recolhidos pela CPI, o cemitério Dom Bosco, em Perus, data de 1971 (gestão do prefeito Paulo Maluf), tendo sido originalmente concebido para receber indigentes. Preconizavase, na ocasião de sua concepção, a instalação de um crematório para este mesmo segmento da população. O cemitério passou a receber os cadáveres de presos políticos em função de um acordo estabelecido informalmente entre o IML/SP, DOI-CODI/SP e DEOPS/SP. Esse acordo foi encabeçado pelo delegado de ordem política do DEOPS / 
SP, Alcides Cintra Bueno, e Harry Shibata, membro da diretoria do IML/SP, visando à ocultação dos vestígios das mortes dos militantes (CALIGIURI FILHO, 1992, p. 11), sob o mote de se garantir uma aparência de legalidade às práticas repressivas do regime de exceção.

Em depoimento à CPI, o delegado Josecyr Cuoco confirmou suspeitas aventadas por sobreviventes e pelo BNM de que os sepultamentos clandestinos estiveram associados à ação de um grupo do DOI-CODI/SP especialmente treinado para matar, chamado "GTA", comandado por um tenente da Política Militar. Este grupo simulava as mortes sob tortura produzindo versões falsas em que se apontavam variadas causas para os óbitos, tais como tiroteios, tentativas de fuga, atropelamento, suicídio, acidentes de automóvel; em outras ocasiões, também desapareciam com as pessoas sem produzir justificativas. As práticas que forjaram falsas versões para os assassinatos de presos políticos e a ocultação de seus corpos, alterando os procedimentos do IML e dos cemitérios de São Paulo, foram documentadas e nos informam sobre a articulação e o controle exercidos pelos órgãos responsáveis pela segurança interna (CALIGIURI FILHO, 1992, p. 25, p. 41).

Sabe-se que, pelo menos 19 corpos de militantes assassinados foram enterrados no Cemitério D. Bosco12, dez deles com nomes falsos e, desses, seis provavelmente ficaram na vala clandestina. Apenas um corpo desse total era considerado desaparecido. Seu nome era Luiz Eurico Tejera Lisbôa, enterrado como Nelson Bueno. Das prováveis 6 pessoas enterradas na vala comum, 5 eram sabidamente mortas, mas seus corpos foram ocultados dos familiares, e uma era considerada desaparecida. Os demais foram recuperados aos poucos pelas respectivas famílias durante os anos de 1970 e 1980, apesar de terem sido enterrados com seus nomes verdadeiros.

Os sepultamentos clandestinos envolviam procedimentos padronizados, o que nos permitiu compreender de maneira clara a sua lógica. O policial militar Miguel Fernandes Zaninello era o responsável por transportar a maioria dos cadáveres de militantes assassinados do IML para o Cemitério Dom Bosco, os quais, geralmente, eram sepultados como indigentes. Ele era também o declarante de grande número de atestados de óbitos. Quando chegava ao cemitério, os sepultadores sempre lhe perguntavam se haveria 
"algum especial" para enterrar. Esta era a maneira como denominavam os presos políticos assassinados. Segundo Jair Romeu, o auxiliar de autópsia do IML/SP, ele próprio marcava com a letra "T" de terrorista, em vermelho, todas as solicitações de exame necroscópico e laudos referentes a esses militantes. Várias requisições de exame possuíam anotação indicando seus nomes verdadeiros, no entanto, eram enterrados com o nome falso utilizado na vida clandestina. Diversos documentos encontrados nos arquivos do DEOPS confirmam que os policiais sabiam seus nomes verdadeiros. Jair Romeu seguia as ordens do delegado de Ordem Política, Alcides Cintra Bueno, do DEOPS. Os registros com a letra "T" não apareceram mais depois do final de 1973 (BARCELLOS, 2001, p. 223). No Rio de Janeiro, as solicitações de exame necroscópico e laudos referentes a esses militantes eram grafados com "sub", de subversivo (ALMEIDA, 2009).

As autópsias eram realizadas pelo mesmo grupo de funcionários do IML e, em geral, ocorriam sem o testemunho de ninguém, durante a noite. Segundo Josué Teixeira dos Santos, administrador do necrotério do IML à época, havia uma lista restrita de legistas na escala para estes trabalhos. Um fato digno de nota acerca dessas autópsias refere-se à determinação por parte do então major comandante do DOI-CODI/SP, Carlos A. B. Ustra, de que apenas a cabeça do morto fosse fotografada, de modo a ocultar as marcas de tortura (CALIGIURI FILHO, 1992, p. 20-22). Esse procedimento encontrava como entrave o fato de que o relatório médico legal exige que se responda à possível existência de tortura. Quanto a esta demanda, os legistas frequentemente descreviam as marcas de tortura, ao passo que, na produção das conclusões dos laudos, corroboravam a versão policial, em patente controvérsia quanto àquilo que haviam anotado (ALMEIDA, 2009).

Harry Shibata relatou à CPI que, nas autópsias de presos políticos, não se fazia o corte do crânio, nas ocasiões em que este procedimento se fazia obrigatório e, como tal, registrado no laudo. Constatou ainda que não era hábito manter o morto na geladeira por 72 horas, à espera dos familiares, conforme a determinação da lei (CALIGIURI FILHO, 1992, p. 24). 
As informações produzidas pela CPI levaram à extensão dos trabalhos a todos os cemitérios da capital e cidades vizinhas. Assim, outras ossadas foram encaminhadas ao DML/Unicamp para investigação com fins de identificação.

Um de seus aspectos mais notáveis foi a produção de um número significativo de depoimentos de torturadores, entre policiais e militares que atuaram no DOI-CODI e no DEOPS/SP. Neste sentido, dir-se-ia que a CPI não enfrentou o dilema do projeto $\mathrm{BNM}$ - o de privilegiar a fonte documental em detrimento da oral, apesar de algumas ausências importantes ${ }^{13}$. Muitos não admitiram a participação direta nas práticas de tortura, mas confirmaram sua existência:

[...] Pessoas como o coronel Erasmo Dias acabaram depondo na CPI e até hoje não sei como isso foi possível. Sabendo a história deles e o que eles fizeram, para mim foi uma surpresa ouvir os depoimentos de torturadores confessos. Eles não tiveram nenhum receio ou pudor de confirmar alguns dos crimes bárbaros que cometeram. Esses depoimentos foram caracterizados pelo deboche. Eles falavam debochando, mas falavam. E isso é comum a outros depoimentos de torturadores. Imagino que essa postura fosse necessária para que não sentissem a dimensão da barbaridade que eles cometeram (LAJOLO, 2012).

Estes depoimentos detalharam um pouco mais a distribuição de funções dentro do aparato repressivo, estruturado em São Paulo; através dos mesmos, tornou-se mais clara a integração entre as instâncias repressivas (CALIGIURI FILHO, 1992, p. 28-30), tal como ficou comprovado nas investigações realizadas sobre a logística envolvida nas falsificações de laudos, sepultamentos e ocultações de cadáveres, previamente descritos.

Apesar destas informações, é de se ter em vista que a maioria dos restos mortais de dissidentes não foi recuperada. Uma das razões para tanto são as estratégias empreendidas pela repressão política para a ocultação das evidências. Por exemplo, no cemitério de Vila Formosa, um bosque foi erguido sobre a quadra $\mathrm{n}^{\circ} .10$, originalmente 
destinada aos indigentes, a qual se suspeita que tenham havido sepultamentos de militantes assassinados.

Não obstante, a CPI conseguiu localizar o sítio 31 de março, em Parelheiros (SP). Este sítio era utilizado pelo delegado Sérgio P. Fleury (CALIGIURI FILHO, 1992, p. 30, p. 34) e o DOI-CODI/ SP para torturar, infiltrar ex-militantes nas organizações de esquerda e, eventualmente, fazer desaparecer militantes considerados "irrecuperáveis". O sítio seria um correspondente paulista da Casa da Morte de Petrópolis (RJ) (TELES, 2011). As escavações realizadas no local, contudo, não encontraram restos mortais.

Os testemunhos de familiares e sobreviventes ouvidos pela CPI tiveram grande impacto (CALIGIURI FILHO, 1992) e deram visibilidade às histórias dos militantes assassinados, assim como à reivindicação de reconhecimento e pela responsabilização desses crimes. Estes depoimentos expressaram um exercício público de evocação que permitiu ampliar o conhecimento sobre a história e as memórias da ditadura.

É digno de nota que a CPI não tenha enfrentado pressões políticas significativas ou mesmo ameaças, conforme o relato de Teresa Lajolo:

[...] Nós não sofremos nenhuma ameaça ou pressão política. Quando fomos investigar o sítio 31 de março, apesar do temor que sentimos no início, não tivemos problemas. Conseguimos o apoio do COE, da Polícia Civil e do Serviço Funerário [...]. Aquele foi um momento político muito especial, tudo era novidade. Acho que todos foram pegos de surpresa com a abertura da vala.

A pressão foi maior do lado da esquerda, que sempre nos alertava para que não assumíssemos uma postura 'revanchista'. Da nossa parte, a única preocupação era a de contar aquela história (LAJOLO, 2012).

A atmosfera política da CPI foi influenciada pelo entusiasmo provocado pela promulgação da Constituição de 1988 e a realização da primeira eleição direta para presidente depois da ditadura, em 1989. A Constituição incluiu uma série de direitos progressistas em 
várias áreas, ao mesmo tempo em que manteve significativos elementos autoritários, tais como os aspectos relativos ao poder político e às Forças Armadas. $\mathrm{O}$ resultado foi o controle do Exército sobre as forças de segurança pública e a tutela das Forças Armadas sobre os poderes políticos legitimamente instituídos, conforme determina o artigo 142, que trata da ingerência militar nos assuntos civis e do poder político: "As Forças Armadas destinam-se à defesa da pátria, à garantia dos poderes constitucionais e, por iniciativa de qualquer destes, da lei e da ordem" (ZAVERUCHA, 2005, p. 63-64, p. 93-95, p. 122). Os responsáveis pela repressão estatal da ditadura sentiam-se relativamente seguros com a manutenção dos principais artigos da Lei de Anistia e a CPI pôde encaminhar seus trabalhos com certa tranquilidade.

A CPI recomendou um conjunto de propostas e de medidas legais de significativo impacto social, entre as quais se destacam a desvinculação do IML da polícia estadual e a reorganização dos cemitérios municipais. Ao encaminhar os resultados de seu trabalho, a CPI solicitou ao governador que exigisse da União Federal a devolução dos arquivos do DEOPS/SP; e que as irregularidades do IML deveriam ser objeto de uma investigação e os responsáveis punidos. Ao Ministério Público, a CPI solicitou a apuração dos crimes de sequestro, tortura, morte e desaparecimentos forçados relatados na CPI, no âmbito da justiça. E, finalmente, ao presidente da República, recomendou a regulamentação da lei de arquivos (8.159/91), de forma a excluir a possibilidade de manter o sigilo dos documentos relativos à segurança do Estado e da sociedade por 60 anos (CALIGIURI FILHO, 1992).

Alguns reflexos institucionais gerados pelas recomendações da CPI foram sentidos imediatamente, como a abertura irrestrita do arquivo do DEOPS/SP em janeiro de 1992. Muitos desdobramentos, contudo, desenvolveram-se lentamente e de maneira limitada, como as ações judiciais propostas pelo MPF/SP a partir de 2008 e a edição da Lei de Informação, em 2011. 


\section{As investigações dos restos mortais}

Entre 1991 e 1992, impulsionados pela ampla visibilidade dada pela cobertura da imprensa, os trabalhos de investigação da Unicamp levaram à identificação de dois militantes, cujos restos mortais estavam na vala clandestina de Perus. Os esqueletos de outros três militantes enterrados em covas individuais do mesmo cemitério também foram identificados. Neste período, foi possível ainda estabelecer a identidade de uma ossada encontrada no cemitério de Campo Grande ${ }^{14}$. D. Paulo E. Arns oficiou duas missas em homenagem a esses dissidentes assassinados, reeditando as emblemáticas celebrações realizadas na Catedral da Sé nos anos 1970.

Em abril de 1991, pouco depois do final dos trabalhos da CPI da vala de Perus, uma caravana de familiares e entidades de direitos humanos realizada na região da Guerrilha do Araguaia encontrou dois esqueletos de supostos guerrilheiros, os quais foram levados para a Unicamp. Os restos mortais encontrados no cemitério de Xambioá (TO) pertenceriam a Maria Lúcia Petit da Silva, desaparecida desde junho de 1972, e a Francisco Manoel Chaves, assassinado em setembro do mesmo ano. Após longa espera, em maio de 1996, os restos mortais de Maria Lúcia foram identificados e a família pôde realizar os rituais funerários (ALMEIDA, 2009, p. 25-29).

A partir de 1993, após o fim do mandato da prefeita Luiza Erundina, nenhum informe oficial sobre as investigações das ossadas encontradas foi divulgado. Apesar das dificuldades para se chegar ao término das pesquisas, no local onde se encontrava a vala comum, foi erguido um memorial de autoria do arquiteto Ricardo Ohtake, inaugurado em 26 de agosto de 1993, onde, por muitos anos, D. Paulo Evaristo Arns celebrou missa no dia de finados em homenagem aos mortos e desaparecidos políticos.

Em maio de 1995, os familiares e as entidades de defesa dos direitos humanos exigiram a prestação de contas a respeito da pesquisa de identificação das ossadas de Perus e demais cemitérios. Soube-se, então, que fragmentos ósseos dos seis militantes mortos, já identificados pelo DML, haviam sido encaminhados para a Alemanha e fragmentos ósseos de esqueletos não identificados foram enviados para a extração de DNA na Universidade Federal de Minas 
Gerais, em Belo Horizonte. Estabeleceu-se, então, a criação de uma Comissão para garantir a transparência dos trabalhos de investigação do DML. Afiançou-se que as ossadas seriam devolvidas ao cemitério de Perus depois do término das pesquisas e em condições previamente acertadas com os familiares e o DML comprometeuse a enviar relatório detalhado a respeito da investigação realizada.

Após um ano sem resposta da Unicamp, os familiares, mediante interferência do então Secretário da Justiça do Estado de São Paulo, Belisário dos Santos Jr., conseguiram reunir-se com o reitor daquela universidade, o Secretário Adjunto da Secretaria da Segurança Pública e os deputados estaduais Renato Simões e Wagner Lino. Decidiu-se pelo afastamento do Dr. Badan Palhares do processo de investigação das ossadas de Perus; o envio de médicos legistas da Secretaria de Segurança para acompanharem a investigação; a participação de um perito internacional como observador; o envio de questionário elaborado pelos familiares com todas as dúvidas a serem explicadas pela reitoria. O Dr. José Eduardo Bueno Zappa assumiu os trabalhos e o médico legista Carlos Delmonte foi encaminhado pela Secretaria da Segurança Pública para o DML/ Unicamp. As respostas fornecidas através da Procuradoria Geral da Unicamp foram evasivas e contraditórias.

Em abril de 1997, os familiares receberam cópias do relatório Projeto Perus, assinado pelo Dr. Zappa, e do ofício do Dr. Carlos Belmonte. Tanto o relatório (primeiro documento oficial do DML/ Unicamp a respeito das ossadas) quanto o ofício do médico legista da Secretaria de Segurança foram evasivos e dedicados a elogiar o Departamento de Medicina Legal da universidade.

Foi criada, em fevereiro de 1998, uma Comissão Especial para sugerir as providências necessárias à conclusão dos trabalhos de identificação dos dissidentes enterrados na Vala de Perus, presidida pelo médico legista Dr. Antenor Chicarino e composta por familiares e representantes da Secretaria da Cultura e da Justiça do Estado de São Paulo. A Comissão, após realizar vistoria nas dependências da universidade, constatou a precariedade do acondicionamento das ossadas e o comprometimento das investigações, pois os esqueletos estavam em sacos abertos e sem identificação, jogados ao chão sujo de lama, devido à inundação que atingiu o prédio, e com pesados 
móveis sobre os mesmos. Diante dessa situação, a Comissão indicou que fosse feita a transferência das ossadas para o Instituto Oscar Freire, do Departamento de Medicina Legal da USP, um perito internacional como observador e que tal transferência fosse realizada após minuciosa averiguação da situação, quando se estabeleceria um prazo para o término das investigações.

O relatório da Comissão Especial foi entregue aos Secretários da Justiça e da Segurança Pública do Estado de São Paulo em abril de 1998, mas não houve qualquer resposta das autoridades. Em março de 1999, membros da comissão extinta realizaram reunião com o então Secretário da Segurança Pública, Marco Vinícius Petroluzzi, que se comprometeu a se pronunciar a respeito das soluções propostas em 1998.

Cansada de esperar, em março de 1999, a família de Flávio Carvalho Molina, militante do Molipo (Movimento de Libertação Popular) assassinado em novembro de 1971, em São Paulo, propôs Medida Cautelar Incidental com pedido de concessão de liminar para produção de prova, a fim de instruir a Ação de Ressarcimento de Danos proposta em 1992 “[...] no sentido de determinar a imediata perícia - exame de DNA nas ossadas que resta[va]m na Unicamp - [...] mais precisamente as que receberam os números 240 e 57 [...]" (ALMEIDA, 2009, p. 27), para realizar a identificação de seus supostos restos mortais. A ação solicitava que, caso a Unicamp não pudesse realizar tal prova pericial, as ossadas deveriam ser transferidas para local seguro, onde fosse possível fazer o exame necessário.

Em setembro de 1999, o Ministério Público Federal (MPF) instaurou o inquérito civil 06/99, para apurar o encaminhamento dado às investigações dos restos mortais de Flávio Carvalho Molina e das ossadas da vala de Perus, na Unicamp. O MPF, atendendo a uma solicitação do GTNM-RJ, iniciou a apuração porque a universidade, responsável pelas pesquisas desde 1990, não havia apresentado qualquer relatório conclusivo das pesquisas.

Após a realização de diversas diligências, o MPF constatou que não seria mais possível continuar os trabalhos na Unicamp. Em novembro de 2000, a Secretaria de Segurança Pública do Estado de São Paulo indicou o Dr. Daniel Muñoz, professor da Universidade de São Paulo (USP) e médico legista do IML/SP, como responsável 
pelos trabalhos de identificação das ossadas. Promoveu-se, então, em janeiro de 2001, a transferência dos documentos relativos à vala de Perus, bem como das sete ossadas suspeitas de pertencerem a Flávio Carvalho Molina, Hiroaki Torigoe e Luiz José da Cunha para o IML-SP. Além dessas, foi transferida também a ossada do cemitério de Xambioá (TO). No final de maio de 2001, as ossadas restantes foram transferidas para as gavetas do columbário do Cemitério do Araçá, em São Paulo, para serem classificadas.

Após a realização de diversas reuniões com a equipe da USP e do IML, constatou-se que tanto a universidade quanto a Secretaria de Segurança Pública não conseguiram adquirir tecnologia suficiente para a realização desses exames e não aceitaram colaboração da Polícia Federal. Novamente, não foram apresentados documentos, laudos ou relatórios sobre essas possíveis tentativas.

Os familiares solicitaram à Comissão Especial de Mortos e Desaparecidos Políticos (CEMDP) que colaborasse com o MPF para obter recursos financeiros e realizar os exames no laboratório Genomic, de São Paulo. Um de seus sócios é familiar de um preso político assassinado durante a ditadura e, na década de 1990, ofereceu-se para colaborar com a Unicamp, que havia recusado a ajuda.

Desse modo, após 15 anos de tentativas frustradas, foi possível identificar os restos mortais de Flávio Carvalho Molina, em setembro de 2005. Em outubro daquele ano, foi realizada a cerimônia de entrega dos restos mortais de Molina com a presença de seus familiares, companheiros, amigos, autoridades e representantes de movimentos de defesa dos direitos humanos. No dia seguinte, ele foi enterrado no túmulo da família, localizado no cemitério São João Batista, no Rio de Janeiro.

O mesmo encaminhamento foi dado ao exame dos restos mortais de Luiz José da Cunha, dirigente da ALN assassinado em 1973. Em 1997 já haviam sido enviados fragmentos ósseos de sua possível ossada para a Universidade Federal de Minas Gerais com o fim de realizar o exame de DNA. Em 2001, porém, constatou-se que as amostras estavam em condições precárias. Assim, nova coleta de amostra de sangue foi feita em 2005, mas, novamente, a USP não conseguiu fazer a extração de DNA dos ossos. Desse modo, em fevereiro de 
2006, foi enviada uma remessa do material genético para o laboratório Genomic, em São Paulo, e, em junho, obteve-se o resultado positivo.

Em função do tempo transcorrido, bem como os poucos resultados obtidos por meio da atuação de laboratório particular, o MPF exigiu alterações na condução dos trabalhos de investigação das ossadas do cemitério de Perus. A continuidade das pesquisas, entretanto, deparou-se com a dificuldade de localizar as antigas sepulturas dos anos 1970, tendo em vista que foram modificadas as disposições das ruas e a numeração das mesmas. Em setembro de 2007, foram reiniciados os trabalhos, mas estes não obtiveram muitos resultados positivos.

Em 2008, grupos de familiares conseguiram, com a ajuda do $\mathrm{MPF} / \mathrm{SP}$, localizar, exumar e identificar os restos mortais do espanhol Miguel Sabat Nuet, assassinado por integrantes do DEOPS/ SP em 1973 e enterrado no cemitério de Perus. Apenas em 2011, porém, o governo brasileiro entregou-o à família em cerimônia realizada em São Paulo (UCHÔA, 2011).

A análise dos restos mortais segue inconclusa ${ }^{15}$, entretanto, como consequência das investigações iniciadas com a abertura da vala de Perus e o projeto Brasil Nunca Mais, desde 2008, o MPF vem propondo ações civis e criminais visando a responsabilizar os envolvidos no aparato repressivo do período ditatorial. Nenhum desses processos chegou a produzir consequências judiciais definitivas até o momento ${ }^{16}$.

\section{Considerações finais}

A transição brasileira para a democracia ocorreu sem rupturas evidentes, tendo sido pactuada entre as elites civis e militares, após terem sido dadas mostras de que não se remexeria o passado. Neste momento de mudanças, alguns atores e setores sociais buscaram exibir marcas simbólicas e efetivas de rompimento com aquele período histórico, sistematizando e divulgando as denúncias dos crimes da ditadura, tendo em vista propostas e mecanismos de recuperação da verdade jurídica e histórica capazes de transmitir as memórias e o legado da violência da ditadura. 
Desse modo, configurou-se uma democracia pactuada, a qual assegurou a impunidade e a preservação de dispositivos do Estado de Segurança Nacional. Este pacto exemplifica-se pelas leis de exceção remanescentes do período ditatorial, como a Lei de Imprensa (1967) (revogada em 2009) e a Lei de Segurança Nacional (1983), a qual permanece em vigor. Os fundamentos políticos delineados ajudam-nos a compreender o contexto em que se inserem a publicação do relatório do projeto Brasil Nunca Mais (1985), e a abertura da vala clandestina de Perus (1990) que, conforme argumentamos, representam os marcos principais da construção da memória social sobre a violência ditatorial.

A publicação do BNM representou um claro empecilho ao acobertamento dos crimes da ditadura, ainda que seus desdobramentos políticos e institucionais permaneçam tímidos. Apesar de suas consequências práticas limitadas, os ecos traumáticos das denúncias dessas violações compiladas no BNM desempenharam papel decisivo no posicionamento da sociedade civil acerca da extensão dos crimes da ditadura. Esta percepção contribuiu e permanece contribuindo para a limitação do poder e o espaço concedido às forças armadas, no âmbito do aparato burocrático do estado. Finalmente, é de se ter em vista o papel fundamental do BNM na produção de indicações para se lidar com o legado existente, de um ponto de vista jurídico, histórico e cultural.

Já a CPI instaurada a partir da descoberta de ossadas de presos políticos na vala de Perus (1990/91), produziu desdobramentos institucionais mais consistentes, tais como a recomendação para a desvinculação do IML da polícia estadual, a reorganização dos cemitérios municipais, a devolução dos arquivos do DEOPS/SP e a regulamentação da lei de arquivos (8.159/91). Esta lei foi efetivamente revogada em 2011, depois de uma série de modificações e pressões da sociedade civil. Conforme argumentado, a apuração dos fatos envolveu uma rara profusão de depoimentos de torturadores e de agentes da repressão indiretamente envolvidos com a tortura.

Ao passo que alguns países latino-americanos há tempos vêm se dedicando à criação de novos investimentos na memória e na elaboração simbólica e judicial do passado, o Brasil mantém-se como modelo de impunidade e atraso na promoção de uma política 
de reconstituição factual dos crimes da ditadura. Isto contribui sensivelmente para a irresolução desses conflitos, que desse modo seguem impossibilitando as "[...] reconfigurações do campo social e do ordenamento jurídico que poderiam equacionar as exigências de reconhecimento" (SAFATLE, 2005, p. 34) das vítimas e setores sociais atingidos pela ditadura. Trata-se de uma "lógica astuta", pois ao mesmo tempo em que reconhece as demandas das vítimas por reparações, desloca-as para a periferia do universo político em que se discutem as propostas de modificação profunda da sociedade (Idem).

Em conclusão, dir-se-ia que o Brasil avançou a partir das experiências aqui relatadas, mas ao mesmo tempo não soube aproveitar a oportunidade para a geração de processos de justiça e responsabilização que efetivamente refletissem a real magnitude dos eventos consumados.

\section{CONSTITUTING MEMORIES OF THE DICTATORSHIP REPRES- SION: THE BRASIL NUNCA MAIS PROJECT AND THE OPENING OF THE GRAVEYARD OF PERUS}

Abstract: The Brazilian transition to democracy occurred without notable ruptures. Under the strong legacy of the civil-military dictatorship, factual reconstitution and critical thinking about the period remain intertwined with silence zones and interdictions. The historical recollection of the period includes two fundamental events: the publication of the project Brasil Nunca Mais and the opening of the graveyard of Perus. The main goal of this study is to offer a reflexive panorama on the interdiction of the recent past, establishing a narrative centered around these two foundational moments, which have pushed the limits of the negotiated political transition that was implemented in the country. The panorama offered is based upon interviews with persons that were directly involved in these events, rare documents, and an extensive bibliographic review on the matter.

Keywords: Political transition. Torture. Dead and political disappeared. Dictatorship and Memory. 


\section{Notas}

${ }^{1}$ Jaime Wright morreu em 1999, era irmão de Paulo Stuart Wright, dirigente da Ação Popular-Marxista Leninista, desaparecido desde 01/09/73 (ALMEIDA, 2009, p. 456-58).

${ }^{2} \mathrm{O}$ general Ernesto Geisel extinguiu o AI-5, mas incorporou parte do seu conteúdo à Constituição. A reformulação da LSN implicou, basicamente, a redução das penas (ALVES, 1984).

${ }^{3}$ Chamado de Projeto A, em 1987 este material foi doado pela Cúria Metropolitana de São Paulo ao Arquivo Edgar Leuenroth, na Unicamp. Duas cópias foram enviadas para a Europa e a outra para os Estados Unidos. Em 2011, o MPF/SP trouxe para o Brasil os originais do BNM, com o objetivo de copiar esse material e disponibilizá-lo na internet.

${ }^{4}$ WESCHLER (1990); LIMA (2003); FIGUEIREDO (2009) e o site Armazém Memória.

${ }^{5}$ Depoimento de Eny R. Moreira, disponível em < www.dhnet.org.br/memoria/ nuncamais>. Acesso em 05 abr. 2011. Note-se que as entrevistas sobre o BNM registradas em vídeo disponíveis no site Armazém Memória foram realizadas por Marcelo Zelic, mas este não disponibilizou informações sobre duração, data e local das mesmas.

${ }^{6}$ Depoimento de P. Vannuchi. Disponível em: <www.dhnet.org.br/memoria/ nuncamais $>$. Acesso em: 05 abr. 2011.

${ }^{7}$ Depoimento de Luis Eduardo Greenhalgh. Disponível em: <www.dhnet.org. br/memoria/nuncamais>. Acesso em: 05 abr. 2011.

${ }^{8}$ Foram encontrados depoimentos sobre 19 mortos. Posteriormente, Gaspari localizou 129 laudos necroscópicos espalhados nos autos dos processos judiciais do período transcorrido entre 1969-1973 (GASPARI, 2002, p. 385).

${ }^{9}$ Em seguida, formaram-se outros GTNM em SP, MG, PE e PR, entre os mais significativos.

${ }^{10}$ No início dos trabalhos, a Conadep contava apenas com 70 testemunhos de sobreviventes, ao final, conseguiu reunir cerca de 1.200 depoimentos de ex-presos políticos (CRENZEL, 2008, p. 71).

${ }^{11}$ A CPI foi composta por 4 vereadores: Júlio César Caligiuri Filho (presidente), Teresa Lajolo (relatora), Ítalo Cardoso e Vital Nolasco, que substituiu Aldo Rebelo (CALIGIURI FILHO, 1992).

${ }^{12}$ Barcellos levantou 28 nomes de militantes que poderiam estar enterrados no cemitério de Perus (BARCELLOS, 2001, p. 224).

${ }^{13}$ A convocação coercitiva de alguns torturadores notórios não foi possível em função do término do prazo dos trabalhos da CPI (CALIGIURI FILHO, 1992, p. 9).

Anos 90, Porto Alegre, v. 19, n. 35, p. 261-298, jul. 2012 
${ }^{14}$ Entre 1991 e 1992 foram identificados dois restos mortais enterrados na vala clandestina de Perus: os de Dênis Casemiro, desaparecido desde 1971, e de Frederico Eduardo Mayr, morto em 1972. Foram identificados ainda os restos mortais de Hélber José Gomes Goulart, Antonio Carlos Bicalho Lana e Sonia Maria de Moraes Angel Jones, assassinados em 1973, localizadas em covas individuais no cemitério de Perus. Do cemitério de Campo Grande, foi identificada a ossada de Emanuel Bezerra dos Santos, também assassinado em 1973; (ALMEIDA, 2009, p. 26). Ver também Vala de Perus, disponível em: <www.desaparecidospoliticos. org.br>. Acesso em 20 fev. 2012.

15 Outra identificação de ossadas ocorreu em 2009. Bergson Gurjão Farias, combatente da Guerrilha do Araguaia desaparecido em 1972, foi enterrado pelos militares no cemitério de Xambioá (TO) sem notificação. Seus restos mortais foram recuperados pela missão de buscas organizada pela CEMDP em 1996, mas identificados apenas em 2009. Veja-se o site $<$ www.torturanuncamais-rj. org.br>. Acesso em: 10 mar. 2011.

${ }^{16}$ Para referências, ver o site <www.ultimainstancia.uol.com.br>. Acesso em: 20 mar. 2012.

\section{Referências}

ALMEIDA, C.; LISBÔA, Suzana; TELES, Janaína de A.; TELES, M. A. de A. (Orgs.). Dossiê Ditadura: mortos e desaparecidos políticos no Brasil (1964-1985). São Paulo: IEVE/Imprensa Oficial, 2009.

ALVES, Maria Helena M. Estado e oposição no Brasil (1964-1984). Petrópolis: Vozes, 1984.

ARQUIDIOCESE DE SÃO PAULO. Brasil Nunca Mais. 22. ed., Rio de Janeiro: Vozes, 1989. . Perfil dos atingidos. Rio de Janeiro, Vozes, 1987.

BARCELLOS, Caco. “O 'Globo Repórter' sobre a vala de Perus”. . In: TELES, Janaína (Org.). Mortos e Desaparecidos Políticos: Reparação ou Impunidade? 2. ed., São Paulo, Humanitas/FFLCH-USP, 2001.

BAUER, Caroline Silveira. "A produção dos relatórios Nunca Mais na Argentina e no Brasil: aspectos das transições políticas e da constituição da memória sobre a repressão". In: Revista de História Comparada, v. 3, n. 4, 2008. Disponível em: <http://www.hcomparada.ifcs.ufrj.br/revistahc/revistahc.htm>. Acesso em: 11 mar. 2011. 
CALIGIURI FILHO, Júlio César et al. Onde estão? Relatório da Comissão Parlamentar de Inquérito que investigou a vala clandestina no Cemitério Dom Bosco, em Perus, e os desaparecidos políticos. São Paulo, Câmara Municipal de São Paulo, 1992.

CAMARGO, Ana Maria de Almeida. Entrevista concedida à Janaína de A. Teles. SP, $14 / 04 / 2011$.

CAPELATO, Maria Helena R. Memórias da ditadura militar argentina: um desafio para a história. São Paulo, 2007, mimeo.

CRENZEL, Emilio. La bistória política del Nunca Más. La memória de las desapariciones em la Argentina. Buenos Aires, Siglo XXI, 2008.

FIGUEIREDO, Lucas. Olho por olbo: os livros secretos da ditadura. Rio de Janeiro: Record, 2009.

GASPARI, Elio. A Ditadura Escancarada. São Paulo: Companhia das Letras, 2002. JELIN, Elisabeth. Los trabajos de la memoria. Madrid: Siglo XXI, 2002.

LAJOLO, Teresa. Entrevista concedida à Janaína de A. Teles. SP, 10/04/2012.

LICHTSZTEJN, Carlos. Entrevista concedida por à Janaína de A. Teles. SP, 07/05/2010. Arquivo Audiovisual de Presos Políticos/Arquivo Edgard Leuenroth (Unicamp)-Diversitas (USP).

LIMA, Samarone. Clamor. A vitória de uma conspiração brasileira. São Paulo: Objetiva, 2003.

MACHADO, Lenira. Entrevista concedida à Janaína de A. Teles. SP, 09 e 15/04/2009, Arquivo Audiovisual de Presos Políticos/Arquivo Edgard Leuenroth (Unicamp)-Diversitas (USP).

RICOEUR, Paul. A memória, a bistória, o esquecimento. Campinas: Unicamp, 2007.

SAFATLE, Vladimir. Encontro marcado. Reportagem, n. 65, fev./2005, p. 31-34.

TELES, Janaína de A. Os herdeiros da memória: a luta dos familiares de mortos e desaparecidos políticos por "verdade e justiça”" no Brasil. (Mestrado em História) FFLCH, USP, 2005.

- Memórias dos cárceres da ditadura: as lutas e os testemunhos dos presos políticos no Brasil. (Doutorado em História) FFLCH, USP, 2011.

TRAVERSO, Enzo. El pasado, instruciones de uso. Historia, memoria, politica. Madrid: Marcial Pons, 2007. 
UCHÔA, Marcelo. Governo federal entrega restos mortais aos familiares de Miguel Sabat Nuet. São Paulo, 14/12/2011. Disponível em: <http://marcelouchoa.blogspot.com.br>. Acesso em: 20 dez. 2011.

WESCHLER, Lawrence. Um milagre, um universo: o acerto de contas com os torturadores. São Paulo: Companhia das Letras, 1990.

WINTER, Jay. A geração da memória: as reflexões sobre "boom da memória" nos estudos contemporâneos de história. In: SELIGMANN-SILVA, Márcio (Org.). Palavra e imagem: memória e escritura. Chapecó, Argos, 2006.

ZAVERUCHA, Jorge. FH, Forças Armadas e Polícia. Entre o autoritarismo e a democracia (1999-2002). Rio de Janeiro: Record, 2005.

Recebido em: 31/05/2012

Aprovado em: 11/07/2012 